\title{
Mifepristone safety and efficacy in preinduction of labor: an observational study
}

\author{
Thota Sai Tejaswi, Shailaja R. Bidri*
}

\begin{abstract}
Department of Obstetrics and Gynaecology, BLDE (Deemed to Be University) Shri B. M. Patil Medical College Hospital and Research Center, Vijayapura, Karnataka, India
\end{abstract}

Received: 31 December 2020

Revised: 05 February 2021

Accepted: 06 February 2021

\author{
*Correspondence: \\ Dr. Shailaja R. Bidri, \\ E-mail: drsrbidri1@ gmail.com
}

Copyright: () the author(s), publisher and licensee Medip Academy. This is an open-access article distributed under the terms of the Creative Commons Attribution Non-Commercial License, which permits unrestricted non-commercial use, distribution, and reproduction in any medium, provided the original work is properly cited.

\begin{abstract}
Background: When the continuation of pregnancy adversely affecting the mother and fetus, termination of pregnancy is planned. Mifepristone as a method of pre-inducing agent in late pregnancy by increasing sensitivity of the uterus to the actions of prostaglandins and increasing uterine contractility. Objective of this study is to know the efficacy of mifepristone as a preinduction cervical ripening and induction of labor.

Methods: In this prospective randomized study, 130 pregnant women are included and divided into two groups i.e. study group $(n=65)$, has received tab mifepristone $200 \mathrm{mg}$ and control group $(\mathrm{n}=65)$ has not received any drug. After the end of 24 hours, Bishops score in both the groups are assessed and those not in labor or with unfavourable cervix are administered with intracervical dinoprostone gel every 6 hourlies for maximum of 3 doses or until pregnant woman entered into active labor. Statistical analysis regarding improvement in Bishops score, induction active phase interval, induction delivery interval is observed.

Results: After 24 hours, observation in the mean Bishops score has showed significant improvement in the study group $(72.33 \%)$, when compared to control group $(54.58 \%)$. \% woman has gone into spontaneous labor in study group $(61.5 \%)$, and in control group $(75.4 \%)$. Induction to active phase time duration is less in study group with mean (10.53), and in control group (17.4). Induction to delivery time duration is also less in study group with mean (15.100) when compared to control group (22.100). $67.7 \%$ of patients has delivered by vaginally in study group, and in control group $41 \%$.

Conclusions: Tab. mifepristone $200 \mathrm{mg}$ has a pre inducing agent for cervical ripening, shown better improvement in Bishops score within 24-48 hours and decreases time duration from induction to active phase and induction to delivery.
\end{abstract}

Keywords: Bishops score, Dinoprostone gel, Induction of labor, Mifepristone

\section{INTRODUCTION}

When the continuation of pregnancy adversely affecting the mother and fetus and intrauterine environment is not suitable for the fetus, termination of pregnancy is planned. Cervical favourability helps in predicting the success of vaginal delivery, if there is no contraindication for vaginal delivery, in developed countries prevalence of induction of labor is $20 \% .^{1}$ Induction of labor helps in achieving good maternal and peri natal outcome. ${ }^{2,3}$ There are various methods available for preinduction cervical ripening and induction of labor. During pregnancy progesteron is responsible for uterine quiescence. Anti progestin like Mifepristone helps in initiation of labor 
because of its high affinity to progesterone receptors. It is not a 19 nor -steroid, blocks the actions of progesterone at cellular level. Mifepristone is characterized by rapid absorption and long half-life of 25-30 hours. $^{4}$ Mifepristone is potential as a method of inducing labor in late pregnancy but insufficient information available from clinical studies supporting the use of mifepristone as a pre inducing agent for cervical ripening. ${ }^{5}$ Therefore this study is carried to know safety and efficacy of mifepristone as a preinducing agent in cervical ripening. Aims and objectives were to assess safety and efficacy of mifepristone as a preinducing agent for cervical ripening, to critically evaluate the effect of these drugs on primigravida and multigravida, to study improvement in bishop score and to study induction delivery interval.

\section{METHODS}

This study is a prospective randomized control trial to know the safety and efficacy of oral mifepristone as a preinducing cervical ripening agent for induction of labor. This study is conducted over a period of one and half year from December 2018 to July 2020. This study is conducted in Shri BM Patil medical college hospital and research center with a sample size of 130 .

Inclusion criteria includes maternal age $>18$ years, singleton pregnancy, cephalic presentation, period of gestation more than 40 weeks gestation, reactive NST pattern in live fetus, intact membranes, bishops score $<6$, pregnancy induced hypertension. Exclusion criteria includes women with any contraindication to induction and vaginal delivery, estimated fetal weight $>4.5 \mathrm{~kg}$ or $<2000$ gm, antepartum hemorrhage (abruption placenta, placenta previa), previous caesarean sections, abnormal Doppler studies and NST, severe oligohydramnios [AFI$<5]$, chorioamnionitis, major cephalopelvic disproportion, parity $>4$, patients requiring immediate delivery, severe pre eclampsia, eclampsia, diabetes mellitus in pregnancy, intrauterine death.

\section{Methodology}

After taking written informed consent, history, examination, confirmation of diagnosis and investigations, pregnant woman are allocated into study and control groups. Pregnant woman in the study group $(n=65)$ has received tab. mifepristone $200 \mathrm{mg}$ orally and pregnant woman in the control group $(n=65)$ has not received anything and observed for 24 hours. After 24 hours all pregnant woman are assessed for improvement in Bishops score. If Bishops score is $<4$ then intracervical dinoprostone gel is applied every $6^{\text {th }}$ hourly for the maximum of three doses or till the patient into active labor. Once woman went into active labor augmentation of labor is done with oxytocin after 6 hours from the last dose of intracervical dinoprostone gel application. After 3 doses of intracervical dinoprostone gel application, if the woman has not entered into active labor, it is considered as failure of induction and planned for caesarean section. The safety and efficacy of, mifepristone is assessed.

\section{Primary outcomes}

Improvement in Bishops score after 24 hours, number of doses of Dinoprostone gel required for induction, induction delivery interval, number of women going into spontaneous labor within 24 hours.

\section{Secondary outcomes}

Secondary outcomes relate to measures of effectiveness, complications and satisfaction:

Mode of delivery, neonatal outcomes.

\section{Statistical analysis}

In this study continuous variables were presented as mean with standard deviation. Difference in continuous variables is analyzed with test of significance of difference between two means. The difference in proportion was tested with Chi-square test, unpaired ' $t$ ' test and Fishers exact test is applied for statistical evaluation. The demarcating level of statistical significance was at the probability level of 0.05 .

\section{RESULTS}

Out of 130 pregnant woman for the study, are comparable with respect to the mean age and gestational age, which is similar in both the groups (Table 1).

Table 1: Characteristic of patients.

\begin{tabular}{|llll|}
\hline Characteristic & Study group $(\mathbf{n = 6 5})$ & Control group $(\mathbf{n}-\mathbf{6 5})$ & P value \\
\hline Mean age $($ mean \pm SD) & $22.82 \pm 3.77$ & $23.66 \pm 3.501$ & 0.0815 \\
\hline Mean gestational age $($ mean \pm SD) & $39.66 \pm 1.350$ & $39.88 \pm 1.241$ & 0.343 \\
\hline
\end{tabular}

Characteristic of patients according to age shown in Figure 1 comparing basic variables in between two groups.
Significant improvement in Bishops score is observed in study group after 24 hours is with mean $(7.97 \pm 2.845)$ 
than in control group with mean value $(7.87 \pm 2.887)$ with $\mathrm{P}$ value 0.950 .

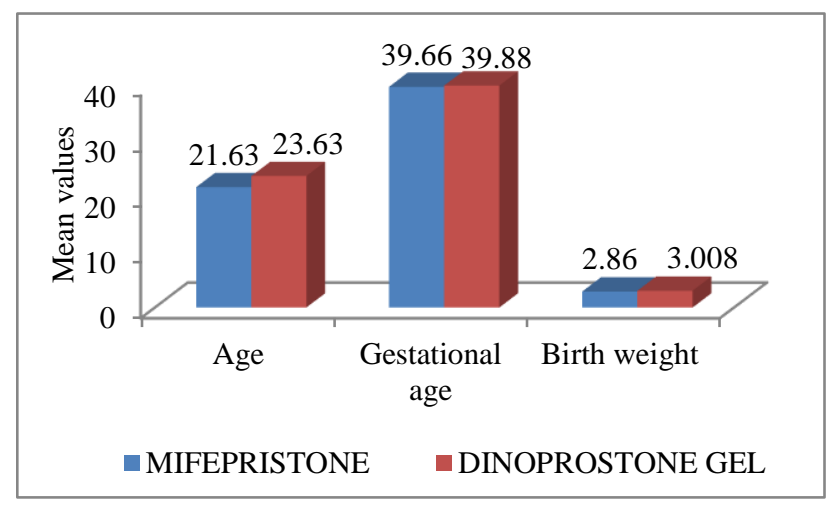

Figure 1: Comparing basic variables in between two groups.

On comparsion of time duration from induction to active phase and induction to delivery is comparable and is having statistically significant value (Table 2) and is shown the form of Figure 2.

Table 2: Comparison of time interval between induction to delivery.

\begin{tabular}{|llc|}
\hline $\begin{array}{l}\text { Characteristic } \\
\text { Induction to } \\
\text { active phase }\end{array}$ & $10.53 \pm 4.050$ & $17.21 \pm 5.968$ \\
\hline $\begin{array}{l}\text { Induction to } \\
\text { delivery }\end{array}$ & $15.100 \pm 5.7$ & $22.100 \pm 6.6$ \\
\hline $\begin{array}{l}\text { Highly } \\
\text { significant }\end{array}$ & & \\
\hline
\end{tabular}

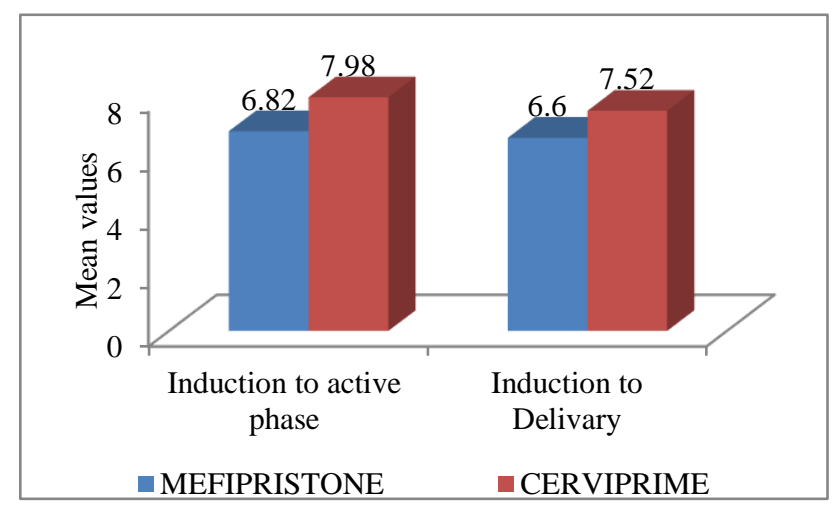

Figure 2: Time interval from induction to delivery.

Table 3: Mode of delivery.

\begin{tabular}{|llll|}
\hline $\begin{array}{l}\text { Mode of } \\
\text { delivery }\end{array}$ & Study group & $\begin{array}{l}\text { Control } \\
\text { group }\end{array}$ & P value \\
\hline Vaginal & $44(67.7 \%)$ & $41(63 \%)$ & 0.4992 \\
\hline LSCS & $22(32.3 \%)$ & $24(37 \%)$ & \\
\hline
\end{tabular}

On comparison of mode of delivery in study group $44(67.7 \%)$ woman has normal vaginal delivery and in control group $41(63 \%)$ woman has normal vaginal delivery (Table 3 ) shown in the Figure 3.

\section{DISCUSSION}

Various methods are available for induction of labor with the aim of achieving successful vaginal delivery. In this study tab .mifepristone $200 \mathrm{mg}$ is used as an adjuvant to intracervical dinoprostone for cervical ripening and labor induction. As reported by Hapangamma and Neilson single dose of mifepristone $200 \mathrm{mg}$ is found to be effective for cervical ripening at 72 hours ( RR2.13, 95\% ci 1.15-3.97 )..$^{5}$ This study correlating with the findings of Hapangama and Neilson, they have recorded high incidence in women going into spontaneous labor and having fvourable cervix (RR2.9,95\% CI 1.70-3.42). Similar finding is also reported by Yelakar et al and Atawale et al. ${ }^{6}$ This study showed significant improvement in Bishops score after 48 hours. Number Of dinoprostone gels used is less in study group than in control group (145 vs 188). In this study significant number of woman has went onto spontaneous labor without requirement of further induction and augmentation with oxytocin. The incidence of caesarean section is also less in study group I this study which is correlating with the study done by Hapangama and Neilson and Fathima et al. ${ }^{5,7}$

This study has several limitations. This study is useful in patients with multigravida and not requiring any emergency delivery in view of fetal indications and maternal indications. This study has not included patients with previous caesarean section.

\section{CONCLUSION}

As there is increasing trend of induction of labor for various reasons, it is necessary to know better modalities for cervical ripening and induction of labor to achieve successful vaginal deliveries with less maternal and neonatal morbidity. Mifepristone is associated with an increasing chance of vaginal delivery. Mifepristone is used as an adjuvant 24 hours prior to intracervical dinoprostone gel is an effective intervention for better cervical ripening, induction of labor reducing need for further doses of dinoprostone gel, without increasing maternal and neonatal morbidity. Hence it is a safe efficient, economical and conveint inducing agent for induction of labor for woman at term. Further studies may recommended and it justify trials comparing mifepristone with dinoprostone gel for cervical ripening agents currently in use.

\section{Funding: No funding sources}

Conflict of interest: None declared

Ethical approval: The study was approved by the Institutional Ethics Committee 


\section{REFERENCES}

1. Mealing NM, Roberts CL,Ford JB ,Simpson JM, Morris JM. Trends in induction of labor ,1998-2007 : a population -based study. Aust N Z J Obstet Gynaecol. 2009;49:599-605.

2. Gulmezoglu AM, Crowthet CA, Middleton P. Induction of labour for improving birth outcomes for women at or beyond term. Cochrane Database Syst Rev. 2006;CD004945.

3. Smith GC. Life-table analysis of the risk of perinatal death at term and post term in singleton pregnancies. Am J Obstet Gynaecol. 2001:489-96.

4. Heikinheimo O. Clinical pharmacokinetics of mifepristone. Clin Pharmacokinet. 1997;33:7-17.
5. Hapangama D, Neilson JP. Mifepristone for induction of labpr. Cochrane Database Syst Rev. 2009;(3):CD 002865 .

6. Athawale R, Acharya N, Samal S, Hariharan C. Effect of mifepristone in cervical ripening for induction of labor. Int $\mathrm{J}$ Repord Contracept Obstet Gynaecol. 2013;2(1):35-8.

7. Fathima S, Nayak SR, Rao B. Mifepristone in induction of labour at term. Int J Pharm Biomed Res. 2013;4(3):164-6.

Cite this article as: Tejaswi TS, Bidri SR.

Mifepristone safety and efficacy in preinduction of labor: an observational study. Int J Reprod Contracept Obstet Gynecol 2021;10:1027-30. 